10. Mosiichuk T.Ye. Sotsialna reabilitatsiia sotsialno-depryvovanykh katehorii naselennia [Social rehabilitation of socially deprived categories of the population]: sotsiolohichnyi pidkhid: dys. ... kand. nauk. K., 2008. 190 p.

11. Muliarchuk V.M., Romaniuk I.M. Osoblyvosti orhanizatsii sotsialnoi roboty iz osobamy, yaki povernulys iz mists pozbavlennia voli [Features of the organization of social work with persons who have returned from places of imprisonment]. Visnyk Natsionalnoho universytetu oborony Ukrainy. 2014. Vyp. 2(39). P. 114-117. URL: http://nbuv.gov.ua/j-pdf/ Vnaou 2014 2 23.pdf.

12. Natochii A.M. Sotsialno-pedahohichna reabilitatsiia vykhovantsiv zahalnoosvitnikh shkil-internativ [Socio-pedagogical rehabilitation of pupils of boarding schools]: navch.-metod. posibnyk. Mykolaiv: Ilion, 2004. 240 p.

13. Ovcharova R.V. Spravochnaia kniga sotcialnogo pedagoga [Social education reference book]. M.: Sfera, 2001.480 p.

14. Pro sotsialnu robotu $\mathrm{z}$ ditmy ta moloddiu [About social work with children and youth]: Zakon Ukrainy № 2558- III vid 21.06.2001r. № 42. 213 p.

15. Prohrama diialnosti Kabinetu Ministriv Ukrainy [Program of activities of the Cabinet of Ministers of Ukraine]. URL: https:/www.kmu.gov.ua/storage/app/uploads/public/5ee/39a/831/5ee39a8311f68625529299.pdf.

16. Psykholoho-pedahohichna reabilitatsiia ditei, vyluchenykh iz pratsi na vulytsi [Psychological and pedagogical rehabilitation of children removed from work on the street] / za red. O.P. Petroshchuk, I.I. Tsushko. K.: Nika-Tsentr, 2003. 232 p.

17. Reabilitatciia i sotcialnaia reintegratciia zakliuchennykh. Upravlenie OON po narkotikam i prestupnosti [Rehabilitation and social reintegration of prisoners. United Nations Office on Drugs and Crime], 2020. URL: https://www.unodc.org/ dohadeclaration/ru/news/2020/11/with-metalwork-and-woodwork--unodc-supports-prisoner-rehabilitation-in-tajikistan.html.

18. Sevostianova N.I. Humanizatsiia protsesu vidbuvannia pokaran - holovnyi element reformy penitentsiarnoi sluzhby [Humanization of the penitentiary process is the main element of the penitentiary service reform]. URL: https://radako. com.ua/news/gumanizaciya-procesu-vidbuvannya-pokaran-golovniy-element-reformi-penitenciarnoyi-sluzhbi.

19. Sotsialna robota [Social work]: korotkyi entsyklopedychnyi slovnyk. K.: DTsSSM, 2002. Kn. 4. 384 p.

20. Chernyshov D.V. Odne z holovnykh zavdan reformy penitentsiarnoi systemy - reabilitatsiia ta resotsializatsiia uviaznenykh [One of the main tasks of the penitentiary system reform is the rehabilitation and re-socialization of prisoners], 2018. URL: https://minjust.gov.ua/news/ministry/denis-chernishov-odne-z-golovnih-zavdan-reformi-penitentsiarnoi-sistemi--reabilitatsiya-ta-resotsializatsiya-uvyaznenih.

21. Shevtsov A.H. Osvitni osnovy reabitolohii [Educational basics of rehabilitation]: monohrafiia. K.: Lesia, 2009. 483 p.

DOI https://doi.org/10.51647/kelm.2020.3.2.44

\title{
COMMON AND DISTINCTIVE SIGNS OF ELECTRONIC MEANS OF PAYMENT
}

\author{
Serhii Chaplian \\ Graduate Student at the Department of Business Law \\ F. H. Burchak Scientific Research Institute of Private Law and Business of Nationality Academy of Law \\ Sciences of Ukraine (Kyiv, Ukraine) \\ ORCID ID: 0000-0002-1765-1323
}

\begin{abstract}
This article is about exploring the characteristics of electronic means of payment, primarily electronic money and virtual currencies. Despite the large number of studies on the issuance and circulation of these objects, almost all of them study either cryptocurrencies or electronic money, without paying attention to a comprehensive approach to electronic means of payment. As a result, scientific sources do not provide a holistic view of electronic means of payment as a set of specific objects that exist in electronic form and, along with money, are used to make payments. In addition, scientists do not understand which objects belong to this set. This article contains an analysis of the key characteristics of electronic money and virtual currencies, their legal nature and legal regime in circulation. The result is a generalization of common and distinctive features of these objects and the conclusion that there are sufficient grounds for their comprehensive regulation. The obtained results provide grounds both for further joint research of these legal institutions, and lay the direction for the development of relevant regulations on the regulation of the issuance and circulation of electronic means of payment.
\end{abstract}

Key words: electronic money, virtual currency, cryptocurrency, crypto-asset, stablecoins, monetary substitute.

\section{СПІЛЬНІ ТА ВІДМІННІ ОЗНАКИ ЕЛЕКТРОННИХ ЗАСОБІВ ПЛАТЕЖУ}

\author{
Чаплян Сергій \\ аспірант кафедри господарського права \\ Науково-дослідного інституту приватного права і підприємниџтва імені академіка Ф. Г. Бурчака \\ Начіональної академії правових наук України (Київ, Україна) \\ ORCID ID: 0000-0002-1765-1323
}

Анотація. Статтю присвячено дослідженню характерних ознак електронних засобів платежу, насамперед електронних грошей і віртуальних валют. Незважаючи на велику кількість досліджень емісії та обігу зазначених 
об'єктів, майже всі вони стосуються лише окремих складників структури електронних засобів платежу - криптовалют, електронних грошей тощо, не приділяючи уваги комплексному підходу до аналізу множинності цих засобів. У результаті в наукових джерелах відсутнє цілісне уявлення про електронні засоби платежу як сукупність специфічних об'єктів, що існують в електронній формі й паралельно з грошима використовуються для здійснення платежів. Крім того, відсутнє розуміння, які об’єкти належать до вказаної сукупності. У статті на основні аналізу ключових характеристик електронних грошей і віртуальних валют, їх правової природи та правового режиму в обігу проведено узагальнення спільних та відмінних ознак цих об'єктів і зроблено висновок про наявність достатніх підстав для їх комплексного нормативно-правового регулювання. Отримані результати як дають підстави для подальшого спільного дослідження цих правових інститутів, так і закладають напрям для розроблення відповідних нормативно-правових актів щодо регулювання емісії та обігу зазначених об'єктів.

Ключові слова: електронні гроші, віртуальні валюти, криптовалюти, криптоактиви, стейблкоїни, грошові сурогати.

\title{
TYPOWE I CHARAKTERYSTYCZNE CECHY ELEKTRONICZNYCH ŚRODKÓW PLATNICZYCH
}

\author{
Chaplian Serhii \\ spirant Katedry Prawa Gospodarczego \\ Instytutu Naukowo-Badawczego Prawa Prywatnego i Przedsiębiorczości im. akademika F. G. Burczaka \\ Narodowej Akademii Nauk Prawnych Ukrainy (Kijów, Ukraina) \\ ORCID ID: 0000-0002-1765-1323
}

\begin{abstract}
Adnotacja. Artykuł poświęcony jest badaniu charakterystycznych cech elektronicznych środków płatniczych, przede wszystkim pieniądza elektronicznego i walut wirtualnych. Pomimo dużej liczby badań emisji i obiegu tych obiektów, prawie wszystkie dotyczą tylko poszczególnych elementów struktury elektronicznych środków płatniczych - kryptowalut, pieniądza elektronicznego i tym podobnych, nie zwracając uwagi na zintegrowane podejście do analizy wielości tych funduszy. W rezultacie w źródłach naukowych brakuje całościowego pojęcia elektronicznych środków płatniczych jako zbioru określonych obiektów, które istnieją w formie elektronicznej i równolegle z pieniędzmi są wykorzystywane do dokonywania płatności. Ponadto brakuje zrozumienia, które obiekty odnoszą się do określonej całości. W tym artykule na temat podstawowych analiz kluczowych cech pieniądza elektronicznego i walut wirtualnych, ich natury prawnej $\mathrm{i}$ reżimu prawnego $\mathrm{w}$ obrocie, podsumowano ogólne i charakterystyczne cechy tych obiektów oraz stwierdzono istnienie wystarczających podstaw do ich kompleksowej regulacji prawnej. Uzyskane wyniki dają podstawy zarówno do dalszego wspólnego badania tych instytucji prawnych, jak i wyznaczają kierunek opracowania odpowiednich aktów prawnych dotyczących regulacji emisji i obiegu tych obiektów.
\end{abstract}

Słowa kluczowe: pieniądz elektroniczny, waluty wirtualne, kryptowaluty, aktywa kryptograficzne, stablkoiny, surogaty pieniężne.

Introduction. In recent decades, the list of traditional means of payment, which, in addition to money, primarily include monetary substitutes, has been supplemented by specific electronic means of payment, which are not money, including non-cash, but can be used to pay for goods, works and services. The question of the legal nature, features of legal regulation of electronic means of payment is under the close attention of scientists, among which we can name A.T. Protsenko, D.S. Vakhrushev, O.V. Zhelezov, S.B. Veprev, I.O. Trubin. However, most research focuses only on certain types of electronic means of payment - electronic money, crypto- or virtual currencies, etc., and does not analyze the problem comprehensively, which, in turn, raises the question of whether it is legitimate to consider these objects homogeneous and belonging to the same class. Accordingly, the purpose of this work is to formulate the general and distinctive features of electronic money, virtual currencies and means of payment that exist in electronic form, in particular, as well as to formulate a conclusion on the feasibility or inexpediency of a single legal regulation of electronic means of payment.

Main part. The task of this work is to analyze the existing electronic means of payment, regulatory framework of their issuance and circulation, approaches to the definition and legal qualification. Using the method of induction, we plan to derive the characteristics of certain types of electronic means of payment, on the basis of which, in turn, to make a synthesis and generalization of common and distinctive features of different types of electronic means of payment.

By electronic means of payment we mean units of value that exist in the form of records on electronic devices, have no material form, are created for their use as exchange and payment units by persons other than the issuer, and circulated by making appropriate entries in their accounting system. Such means of payment include, as noted above, primarily electronic money and virtual currencies.

According to the definition contained in Directive 2009/110/EC of the European Parliament and of the Council on the taking up, pursuit and prudential supervision of the business of electronic money institutions, 'electronic money' means electronically, including magnetically, stored monetary value as represented by a claim on the issuer which is issued on receipt of funds for the purpose of making payment transactions and which is accepted by a natural or legal person other than the electronic money issuer (the European Parliament and the Council, 2009). A feature of electronic money by this definition is its acceptance by a person other than the issuer. Under the legislation of some countries, especially those that do not belong to the European Union, there is no such clarification, and means of payment accepted exclusively by the issuer together with means of payment accepted by third parties belong to the same group. For example, 
in India, special legislation regulates the issuance of so-called prepaid payment instruments Prepaid Payment Instruments or PPIs, which can be: 1) closed system PPIs (generally issued for use only in their respective establishments by business establishments); 2) semi-closed system PPIs (that can be redeemed at a group of clearly identified merchant locations/ establishments that contract to accept the payment instrument specifically with the issuer); 3) semi-open system PPIs (that can be used to purchase goods and services from any card that accepts merchant locations; 4) open system PPIs (that can be used to buy goods and services) (Kumar, 2019).

A similar approach can be found in Japan, where the local Payment Services Act similarly uses the term Prepaid Payment Instruments and separates prepaid payment instruments for own and third-party business: the former are intended solely for settlements with their issuer, the latter can be used in settlements with others (the National Diet, 2009).

Means of payment issued exclusively for settlements with the issuer are very similar to the so-called points or bonuses, which are widely used by network merchants, such as supermarkets, gas stations and the like. Such points (bonuses) are credited to the personal account of the buyer as a reward for certain purchases (in fact, for the money spent). In the future, such points can be used to pay for goods (works, services) from the same seller who charged them. If the seller belongs to a certain network of sellers operating under the same brand, points or bonuses can be used to pay for purchases from each seller of such a network. As noted by I.B. Lagutin, due to the fact that such bonuses can be paid for goods and services, they can also be considered a means of payment (Lagutin, 2015: 19). Like electronic money, points (bonuses) refer to prepaid payment instruments, although unlike electronic money, which is acquired by direct payment (i.e. there is a direct exchange of electronic units for cash or non-cash), points can be acquired by indirect payment (i.e. not by direct redemption, and as a result of the purchase of certain goods (services), which entails the accrual of electronic payment units).

Approaches to the definition of virtual currencies have undergone significantchanges in recentyears, as evidenced by thepositionoftheEuropeanCentralBank(hereinafter-theECB) onthisissue.InOctober2012, theECBstated that"avirtual currency can be defined as a type of unregulated, digital money, which is issued and usually controlled by its developers, and used and accepted among the members of a specific virtual community" (the European Central Bank, 2012: 5). In the report for 2015 it is defined as a digital representation of value, not issued by a central bank, credit institution or e-money institution, which in some circumstances can be used as an alternative to money (the European Central Bank, 2015: 4). In 2016, the position changed again the ECB recommends defining virtual currencies more specifically, in a manner that explicitly clarifies that virtual currencies are not legal currencies or money, "virtual currencies" are not in fact currencies, it would be more accurate to regard them as a means of exchange, rather than as a means of payment (the European Central Bank, 2016: 5).

The position of the European Court of Justice, set out in the judgment of 22.10.2015 in the case of Headquist vs. Sweden, is significant. Describing the virtual currency Bitcoin as a means of payment, the court noted: the 'bitcoin' virtual currency is a direct means of payment between the operators that accept it (the European Court of Justice, 2015: 7).

Not the leastattention is paid to virtual currencies in Directive 2018/843/EU of the European Parliament and of the Council of the European Union amending Directive 2015/849/EU, which, in particular, emphasizes the differences between virtual currencies on the one hand and money, electronic money, game currencies and local currencies on the other. This document draws attention to the recognition of the possibility of using virtual currencies as a means of payment, a means of exchange, investment, a product for savings, etc. Although virtual currencies can frequently be used as a means of payment, they could also be used for other purposes and find broader applications such as means of exchange, investment, store-of-value products or use in online casinos (the European Parliament and the Council, 2018).

Very often the term "virtual currencies", including in scientific sources, includes cryptocurrencies, but the identification of these concepts is not justified. Historically, cryptocurrencies have, in fact, become the first and most popular example of virtual currencies today. However, from a technical point of view, the algorithm of cryptocurrency existence is based on the capabilities of cryptography, and the concept of virtual currencies is not confined to the cryptographic aspect, allowing the existence of other technologies, the development of which can launch a similar product. excellent in matters of technical support. The term "cryptocurrency", which was first published in the international magazine Forbes in 2011 in the article "Crypto currency" (Tanklevskaya, 2017: 134), in recent years is gradually being replaced by another - cryptocurrencies, which is related to first of all, with the influence of state and interstate institutions. He declared himself most loudly at the interstate level in the decisions adopted as a result of the G20 summit held on March 19-20, 2018. In the final communiqué, the summit participants moved away from the use of the term cryptocurrency, replacing it with crypto-assets, directly emphasizing that Crypto-assets lack the key attributes of sovereign currencies (Finance Ministers \& Central Bank Governors, 2018). In other words, according to the summit participants, cryptocurrency is not a currency, but a property. This position is explained by the attempt to avoid the identification of cryptocurrencies with money, which would lead to a radical change in the status quo in the money market.

The rapid development of the virtual currency market has resulted in a number of products, different in nature and characteristics. First of all, these are traditional cryptocurrencies. Researchers offer for them radically different definitions, for comparison: 1) the type of decentralized digital currency, the issuance and accounting of which are based on asymmetric encryption and application of cryptographic methods of protection, which are carried out in a distributed computer network (Melnychuk, 2017: 106); 2) universal, virtual, decentralized and convertible digital currency, which can be used to pay for real goods, works, services, as well as which can be a system of accumulation, storage and investment of funds, protected by a cryptographic code, which can be issued by anyone, maintaining their anonymity, and data on mutual settlements are available to each participant with the impossibility 
of their falsification (Tanklevskaya, 2017: 134); 3) a special type of electronic money, which is a code encrypted by a special program, which is calculated by a specific algorithm performed by a group of computing power, recorded, stored on electronic media and accepted as a means of payment, which is characterized by peering, open source, decentralization and absence guaranteed security (Protsenko, 2016: 9).

The following features of traditional cryptocurrencies can be distinguished: 1) decentralization, i.e. the absence of both a single issuer and a single control center that would store information about balances on cryptocurrencies and a list of transactions; 2) anonymity, which is achieved due to the lack of need to indicate the personal data of the sender and recipient of cryptocurrency (Popykov, 2016: 102); 3) no peg to any national currencies; 4) high volatility; 5) the principle of circulation is based on blockchain technology, which allows to store records of transactions in the form of data (program code) in a distributed register in the form of a continuous chain of blocks; 6) from a technical point of view, they are encrypted by special programs with hash codes, which are recorded and stored on electronic media (Protsenko, 2016: 56). The next object of the cryptocurrency market is centralized cryptocurrencies (cryptocurrencies), which are issued by one issuer or a group of issuers. Such issuers can issue their own cryptocurrencies or tokens, and they are not always the means of payment, quite often they are similar to securities or other objects. If such a product is used for a purpose other than the repayment of payment obligations, the term crypto-asset is indeed much more appropriate for it than cryptocurrency. Because the use of such cryptocurrencies does not involve their widespread use as a means of payment, they remain outside the scope of this study. At the same time, the European Banking Authority in its report on cryptocurrencies of January 9, 2019 gave examples when a crypto-asset would qualify as electronic money. In the assessment of the competent authority the token: 1) is electronically stored; 2) has monetary value; 3) represents a claim on the issuer; 4) is issued on receipt of funds; 5) is issued for the purpose of making payment transactions; 6) is accepted by persons other than the issuer (European BankingAuthority, 2019:13). Virtual currencies or cryptocurrencies that have a centralized issuer (group of issuers) and are intended specifically for use in payment transactions are called stablecoins. The key features of stablecoins are as follows: 1 ) there is a centralized issuer or group of issuers; 2) lower level of autonomy compared to traditional cryptocurrencies; 3 ) the presence of a peg to traditional currencies or physical liquid goods (gold, oil, etc.); 4) lower level of volatility compared to traditional cryptocurrencies. As noted by the European Central Bank in spite of the fact that they are all recorded by means of distributed ledger technology, their characteristics differ according to the type of claim they represent, which could make them similar to commercial bank money, electronic money, investment funds or crypto-assets (European Central Bank, 2020: 50).

According to a report by the G7 working group, stablecoins, with many characteristics of traditional cryptocurrencies, seek to stabilize their price by pegging its value to the value of the asset or asset pool. The report identifies three types of stablecoins: the first, issued with a face value, usually expressed in the usual unit of account. Users acquire a direct request to the issuer or underlying assets to repurchase cryptocurrencies at face value in the same currency that was used in the acquisition of cryptocurrencies; the second, issued without nominal value, which make up a share of the portfolio of underlying assets, as in a stock exchange fund; third, the value of which lies in the trust in the issuer (or those who manage it) (G7 Working Group on Stablecoins, 2019: 3). An example of a stablecoin is Tether, a crypto unit issued by Tether Limited. Under the terms of the issue, the value of Tether is 20 percent secured by cash in US dollars.

The next object to consider is the official digital currencies or Central Bank Digital Currency, CBDC. The achievements of the cryptocurrency market and the development of blockchain technology have launched a study of the possibility of introducing an official national currency in electronic form. For example, in 2014, the Central Bank of China set up a research group to develop the state digital currency (Xiao, 2019). The digital yuan is based on the principle of electronic money stored in an electronic wallet. The full launch of the Chinese Central Executive Committee is planned for 2022 (Anstey, 2020). At the same time, the concept of the digital euro is being actively developed in the European Union. As stated in the EBC report for October 2020, the digital euro would be a risk-free form of central bank money (i.e. a digital representation of cash), which means that it is issued by the central bank and remains its liability at all times (the European Central Bank, 2020: 50). Other countries are not left out of these processes, including Ukraine. The National Bank of Ukraine (hereinafter - the NBU) began developing its own digital currency in 2017, and in 2020 presented the concept of e-hryvnia (Kolodyazhny, 2020). In parallel, the NBU tested the blockchain platform technology, issuing a limited amount of e-hryvnia, the operations of which were tested by working groups with the NBU, volunteer companies and the World Bank (the National Bank of Ukraine, 2019). The central banks of South Korea, France, Great Britain, Japan, Sweden, Canada, Switzerland, as well as the US Federal Reserve in partnership with the Massachusetts Institute of Technology (the National Bank of Ukraine, 2019) are also working on developing their own digital currency.

The qualification of the CBDC is a debatable issue. The National Bank of Ukraine defines the Central Securities Depository as a digital form of existing fiat money issued by the central bank and is a legal tender (the National Bank of Ukraine, 2019). In the literature, one can find the opinion that the Central Central Bank is, in fact, a cryptocurrency backed by public money, that is, in other words, it is a digital form of money that can be used on a par with banknotes and non-cash money (Kolodyazhny, 2020). The ECB, on the other hand, opposes the CBDC to cryptocurrencies, stressing that the nature of the digital euro as the CBDC is a risk-free commitment by the central bank, which fundamentally distinguishes it from cryptocurrencies. The ECB emphasizes that one euro costs one euro today and tomorrow, regardless of cash or digital form. At the same time, money from commercial banks and electronic money are the obligations of controlled individuals, and cryptocurrencies, by contrast, are not anyone's obligations at all (the European Central Bank, 2020, 50). 
Of the entire list of electronic means of payment, only the CBDC can be confidently classified as money in the legal sense of the term. It is known that the economic and legal definitions of the term "money" differ significantly. In pre-state societies, belonging to money was determined by custom, social agreement. In public societies, affiliation to money is determined by the competent state bodies that endow, recognize or specifically create objects with the appropriate status. Money as a legal category requires appropriate legal certainty in the form of the will of the state, which creates legal norms and monitors their implementation. From the point of view of law, they are objects of property rights, which in circulation in a certain territory act as universal means of exchange and payment, and are generally recognized as legal tender. The ratio "money = legal tender" is a general rule, which, however, may have some exceptions, not without reason E.V. Predein calls legal tender a subspecies of money (Predein, 2004, 9). For example, British guinea, minted from 1663 to 1813 , was introduced by the then government and certainly belonged to money, but as a means of payment was accepted in terms of shillings, and the rate changed over time: if at first the "value" of the coin was equal to 21 shillings, then later reached even 30 shillings (Gladky, 2006, 41). Shillings and pounds sterling were recognized as legal tender. Another example is the Ithaca hour, the local currency of the city of Ithaca, USA, the name of which is linked to the cost of an hour of work per person. Officially accepted by the authorities, the Ithaca hour belongs to money, is a means of exchange and payment, but is not recognized as a legal means of payment, because, in the terminology of L.A. Lunz, is not a "universal substitute for the fulfillment of property obligations" and "a marginal and coercive means of fulfillment of obligations" (Lunz, 2004: 31).

Completely different objects can be used as money. There is a universal formula: money is everything that people consider money (Selishchev, 2007: 16). This can be a very wide range of objects: in history there are cases when even people themselves were used as money (Weatherford, 2001: 30). Modern cash obviously belongs to things. Non-cash money in physical form is records in accounts, from the point of view of legal nature, most researchers refer to it as liabilities (Braginsky, 2011: 180) or define it as a fiction of cash (Efimova, 1997: 49). However, it is impossible not to notice that the same objects in the status of money and without it have different legal properties. Thus, banknotes and coins as current money are a universal means of exchange and payment, which allows you to buy an unlimited range of goods. But after losing this status (for example, as a result of monetary reform), they remain things, their physical properties do not change, but the place in circulation changes dramatically - from a universal means of exchange and payment, they become ordinary goods, sometimes even individually defined, if, for example, the series and number of a banknote significantly affect its collection value. Thus, the status of money is not the internal nature of the object, but a special legal regime that does not "merge tightly" with the object-carrier, and, accordingly, the object may, under certain conditions, lose it.

Thus, the properties of money as an object of circulation are determined not by the legal nature, but by the special legal regime inherent in money. A clear example: if we assume that non-cash money is binding and the conditional account holder has the right to claim the bank for the appropriate amount of money, it is obvious that the turnover of this right is very specific. As a general rule, the alienation of the right of claim occurs on the basis of a transaction, which in the theory of civil law is called cession - the assignment of the right of claim. Such a transaction has characteristic features, the analysis of which convincingly proves that the transfer of non-cash money has very little similar to the cession and very much similar to the turnover of ordinary things, when the transfer of ownership is evidenced by an entry in a register (in this case). And this, in turn, pushes us to recognize the validity of the conclusion of S. Shimon that non-cash money, not being things in the physical sense, circulate as ideal things - property intangible objects, which are subject to the legal regime of things (Shimon, 2015: 47). This regime arises from the moment of non-cash money and ends from the moment of their loss of such status. For example, if a bank is declared insolvent, the opportunities for money circulation in the accounts of such a bank are lost, the owner of the money becomes a classic creditor in the obligation, acquiring the right to a monetary claim against the bank or another person liable for the bank, but losing this money as a means of exchange and payment.

Thus, a wide range of objects that may not even belong to the same class of civil rights objects can be recognized as money. Cash physically relates to things and circulates accordingly, taking into account its status. Non-cash money is deprived of the physical body, but circulates according to the rules of circulation of things, which allows them to extend the regime of ideal things.

Thus, if the CBDC is, in essence, the electronic embodiment of the national currency, which is recognized as money at the state level by the relevant regulators, then, accordingly, they also fall under the definition of money. In terms of physical form, they are electronic files with information, like electronic money and virtual currencies. In terms of turnover, they are similar to non-cash money, and therefore in circulation the CBDC is also equated to ideal things. The question of their legal nature is debatable. The assignment of the CBDC to liabilities is hardly sufficient grounds, because unlike non-cash money, the CBDC is issued directly by the central bank, which, like cash, does not include a mandatory component in them, and the possession of such money does not give rise to the relationship "creditor - debtor". In other words, the turnover of the CBDC is the same as cash, only in electronic form, or fiction of cash. Therefore, it is possible that in time there will be a question of allocating a separate specific category of objects of civil rights to denote this phenomenon. However, according to the author of the article, it will not be of great practical importance, because the CBDC as electronic files have value only as long as they are able to perform the function of a means of exchange and payment. If banknotes or coins have a certain intrinsic value that remains after they are withdrawn from circulation, as well as the ability to acquire new value, for example, collectibles, then electronic files with specific encrypted information that cannot be used in any way after their withdrawal from circulation are unlikely will have at least some value. Unlike the CBDC, electronic money by its 
legal nature is obviously a right of monetary claim against the issuer, recorded in the form of electronic records, which in circulation acquires the characteristics of exchange and payment units, has an independent value, can circulate in a certain payment system. to pay for goods (works, services). In physical form it is also electronic files with information, in legal mode - ideal things (exchange and payment units). Electronic money is not money because it does not have the key feature of money - absolute liquidity. They are also not legal tender, but are recognized by law as means of payment. From the point of view of comparing electronic money with money, the most relevant category for the former is monetary surrogates, but not in the narrow sense used in Ukrainian legislation, but in the broad sense found in the scientific literature. Under Ukrainian law, monetary surrogates are any documents in the form of banknotes other than the currency of Ukraine, issued by the NBU and made for the purpose of making payments in economic circulation, except for currency values (Verkhovna Rada of Ukraine, 1999). Instead, in scientific sources, monetary surrogates are understood as objects of property rights, including in electronic form, used as a means of payment and (or) exchange for money (Shildina, 2016: 81). If we take the second definition as a basis, electronic money has every reason to be classified in this category.

The situation with the legal status, nature and regime of virtual currencies is even more uncertain, as only some countries recognize them as means of payment, while others, and most of them, reject the payment of these objects. For example, from 01.04.2017 Japan recognized the cryptocurrency Bitcoin as a means of payment (Parker, 2017) as a method of payment, and in February 2018 the Federal Ministry of Finance of the Federal Republic of Germany clarified that virtual currencies are equated to legal tender to the extent in which they have been accepted by the parties to the agreement as alternative contractual and direct means of payment that serve no other purpose than to be used as a means of payment (Bundesministerium der Finanzen, 2018). In contrast, five Chinese government organizations, including the People's Bank, issued a clarification in 2013 that Bitcoin is a special virtual commodity, but not a currency (Wenhao, 2020). It seems that the problem of defining a virtual currency (cryptocurrency, stablecoins) as a means of payment or as a commodity, or as an investment instrument, etc. is not so much in the nature of the phenomenon itself, but in relation to it or a regulator. And this relationship is not due to an objective analysis of the properties, characteristics, features of the circulation of virtual currency, and the monetary policy of the state.

As already mentioned, some cryptocurrencies are similar to securities and, accordingly, cannot be classified as means of payment. At the same time, traditional cryptocurrencies such as Bitcoin are not adapted for any other use than as a means of exchange and payment. The European Court of Justice highlighted this in its judgment in Hedquist vs. Sweden, noting that the virtual currency Bitcoin has no purpose other than that used for payment and accepted for that purpose by some operators (the European Court of Justice, 2015).

Thus, regardless of whether virtual currencies are defined at the legislative level as a means of payment or not, but if they were created specifically for their use in this capacity, if no other useful use is provided by the terms of issue, if they are used it is for the implementation of exchange transactions and debt repayment, they are objectively a means of exchange and payment.

It is worth noting another significant feature of traditional cryptocurrencies compared to other means of payment: if electronic money is tied to a monetary obligation that is performed in cash or non-cash, then traditional cryptocurrencies are not tied to any currency, and exist autonomously, in themselves representing value. Therefore, first, a cryptocurrency payment is not monetary - it is fairer to define it as a "cryptocurrency payment". Second, a cryptocurrency payment alone cannot repay a monetary obligation. Such repayment can only take place indirectly if the parties determine the relationship between the cryptocurrency and the official currency (at this stage such a relationship can only be contractual, no official exchange rates are set by the competent authorities) and innovate, i.e. replace the monetary obligation to transfer cryptocurrency. In this case, the original monetary obligation will be repaid not at the time of transfer of the cryptocurrency, but at the time of entry into force of the agreement on the parties to the innovation.

If we turn to the legal nature of traditional cryptocurrencies, it turns out that among the objects of civil rights known to the science of civil law, it is very difficult to find a counterpart. They do not belong to the objects of the material world, are not obligations, do not meet the characteristics of information as an object of civil rights, do not meet the definition of a computer program, and even less correspond to other known objects. It is possible that in the end, traditional cryptocurrencies (possibly together with the CBDC) will be allocated to a separate class of civil rights objects. As for stablecoins as a means of payment, they are usually binding in nature, as the issuer, by issuing these virtual units, undertakes to maintain them, exchange them for fiat money, and so on. The legal circulation of these objects, as well as the previous ones, are ideal things.

In circulation, electronic money, traditional cryptocurrencies, stablecoins differ technologically, in terms of issuance and transactions, but in general these are the same exchange and payment units that exist in electronic form and are intended for payment for goods (works, services), i.e. for performing the function of a means of payment. And this is their obvious commonality. Unlike non-cash money and the Central Securities Depository, they are not money and legal tender, as they do not have absolute liquidity and the status of a "universal substitute" in property obligations. Electronic money should be classified as monetary substitutes.

Whether virtual currencies can be classified as monetary substitutes is debatable. According to the author of this article, it is possible, despite the above position, that a cryptocurrency payment repays the cryptocurrency obligation itself. But as practice shows, the transfer of a monetary obligation into a cryptocurrency and its subsequent repayment is an inseparable chain of action, and payers, as a rule, do not even think about the fact that they no longer repay 
the monetary obligation. For them, this is the same as repaying a monetary obligation denominated in one currency with another currency (for example, repaying a liability denominated in hryvnias and US dollars). Suffice it to say where the triumphant ascent of Bitcoin began: in 2010, the American Laszlo Hanech bought for 10,000 bitcoins 2 pizzas from a man with the nickname Jercons, which cost \$ 50 (Tanklevskaya, 2017: 134). How to classify this transaction as an exchange or as a payment depends on certain factors and details that we are unlikely to know for sure. But it is clear that the participants clearly did not regard it, as well as millions of others who followed it, as a set of separate actions to translate a monetary obligation into a non-monetary and subsequent repayment of the latter. For them, Bitcoin was a perfectly acceptable substitute for money, used to pay for the value of goods. Given this, the definition of cryptocurrency as a monetary surrogate has good grounds. Moreover, the competent state authorities, including in Ukraine, have repeatedly expressed their position on the classification of cryptocurrencies as monetary surrogates. In particular, the NBU stated that Bitcoin is a monetary surrogate (the National Bank of Ukraine, 2014), but eventually abandoned the idea. However, the reason for the refusal probably lies in the inconsistency of the cryptocurrency with the legal definition of a monetary surrogate. We can assume that if the NBU started from the doctrinal definition of a monetary surrogate, the conclusions would be completely different.

Conclusions. Summarizing the above, we can see that the operation of electronic means of payment is based on different technologies (blockchain or other), the issue is governed by different approaches (prepaid or non-prepaid means of payment), they have different legal nature (obligations or general status of an individual object civil rights, as in traditional cryptocurrencies). But at the same time, despite such obvious differences, by their civil law regime and the peculiarities of turnover and virtual currencies, and electronic money, and stablecoins are ideal disembodied things, and from the standpoint of the ratio of money, these objects have reason to be recognized monetary substitutes in their doctrinal definition (which, incidentally, should encourage the legislator to clarify the legislative definition of the concept of monetary surrogate and the possible introduction of the term "electronic monetary substitute"). These objects, the internal legal nature of which is leveled and replaced by the status of homogeneous units of account, perform exactly the same functions: act as a means of exchange and payment, and have every reason to use as a means of accumulation (and sometimes used as such). In this regard, the position on the expediency of generalized legal regulation of these objects seems to be absolutely justified, as uniform rules of circulation should be developed for electronic means of payment, of course, taking into account the individual characteristics of each of them.

\section{Bibliography:}

1. The European Parliament and the Council. Directive of 16 September 2009 on the taking up, pursuit and prudential supervision of the business of electronic money institutions amending Directives 2005/60/EC and 2006/48/EC and repealing Directive 2000/46/EC. URL : https://eur-lex.europa.eu/legal-content/EN/TXT/?uri=celex\%3A32009L0110.

2. Kumar K. Prepaid Payment Instruments (PPIs) and its Regulations. 2019. URL : https://blog.ipleaders.in/prepaid-paymentinstruments-and-its-regulations/

3. The National Diet. Payment Services Act. Law number:Act No. 59 of June 24, 2009. URL: http://www.japaneselawtranslation. go.jp/law/detail/?id=3078\&vm=02\&re=02.

4. Лагутин И.Б. Альтернативное денежное обращение и региональное (местное) денежное обращение: вопросы теории, практика осуществления и правового регулирования. Провинциальныле научныле записки. № 2. 2015. С. 13-20.

5. European Central Bank. Virtual currency schemes. 2012. URL : https://www.ecb.europa.eu/pub/pdf/other/ virtualcurrencyschemes201210en.pdf.

6. European Central Bank. Virtual currency schemes - a further analysis. 2015. URL : https://www.ecb.europa.eu/pub/pdf/ other/virtualcurrencyschemesen.pdf.

7. European Central Bank. Opinion CON/2016/49 on a proposal for a directive of the European Parliament and of the Council amending Directive (EU) 2015/849 on the prevention of the use of the financial system for the purposes of money laundering or terrorist financing and amending Directive 2009/101/EC. 2016. URL : https://eur-lex.europa.eu/legal-content/EN/TXT/ $\mathrm{PDF} /$ ?uri=CELEX:52016AB0049\&from=EN.

8. European Court of Justice. Reports of Cases Skatteverket v David Hedqvis. 2015. URL : http://eur-lex.europa.eu/legalcontent/EN/TXT/PDF/?uri=CELEX:62014CJ0264.

9. The European Parliament and the Council. Directive 2018/843 of 30 May 2018 amending Directive (EU) 2015/849 on the prevention of the use of the financial system for the purposes of money laundering or terroristfinancing, and amending Directives 2009/138/EC and 2013/36/EU. URL : https://eur-lex.europa.eu/legal-content/EN/TXT/?uri=CELEX\%3A32018L0843.

10. Танклевська Н.С., Петренко В.С., Карнаушенко А.С. Економічна сутність та види криптовалюти у світі. Наукововиробничий журнал «Бізнес-навігатор». 2017. № 4-2 (43). С. 133-138.

11. Communiqué Finance Ministers \& Central Bank Governors 19-20 March 2018, Buenos Aires, Argentina. URL: https://back-g20.argentina.gob.ar/sites/default/files/media/communique_g20.pdf.

12. Мельничук М.О. Віртуальна валюта як юридичний феномен в електронній комерції. Науковий вісник Херсонського державного університету. 2017. № 5. С. 106-109.

13. Проценко А.Т. Правове регулювання обігу електронних грошей в Україні : дис. ... канд. юрид. наук. Київ, 2016.202 с.

14. Попиков А.А. Криптовалюта Bitcoin как финансовый инструмент виртуальной экономики. Вопросы инновационной экономики. 2016. № 6. С. 89-106.

15. European Banking Authority. Report with advice for the European Commission. 2019. URL : https://eba.europa.eu/ documents/10180/2545547/EBA+Report+on+crypto+assets.pdf.

16. European Central Bank. Report on a digital euro. 2020. URL : https://www.ecb.europa.eu/pub/pdf/other/Report_on_a digital_euro 4d7268b458.en.pdf. 
17. G7 Working Group on Stablecoins. Investigating the impact of global stablecoins. 2019. URL : https://www.bis.org/cpmi/ publ/d187.pdf.

18. Xiao B., Wibawa T. China passes cryptography laws, laying framework for a national digital currency. 2019. URL : https://www.abc.net.au/news/2019-10-30/china-passes-cryptography-laws-national-digital-currency/11645984.

19. Anstey C., Chen L., Xie H. China's Digital Currency Could Challenge Bitcoin and Even the Dollar. 2020. URL : https://www.bloomberg.com/news/articles/2020-06-01/china-is-making-cryptocurrency-to-challenge-bitcoin-and-dollar.

20. Колодяжный P. Е-гривня в действии: скоро мы сможем расплачиваться в магазинах цифровой нацвалютой. 2020. URL : https://finance.liga.net/bank/opinion/e-grivnya-v-deystvii-skoro-my-smojem-rasplachivatsya-v-magazinah-tsifrovoy-natsvalyutoy.

21. Національний банк України. Національний банк продовжить вивчати можливість випуску власної цифрової валюти - е-гривні. 2019. URL : https://bank.gov.ua/ua/news/all/natsionalniy-bank-prodovjit-vivchati-mojlivist-vipuskuvlasnoyi-tsifrovoyi-valyuti--e-grivni.

22. Національний банк України. Аналітична записка за результатами пілотного проєкту «Е-гривня». 2019. URL : https://bank.gov.ua/admin_uploads/article/Analitichna_zapiska_E-grivnya.pdf?v=4.

23. Предеин Е.В. «Денежные суррогаты» в экономике России. Ӓвтореферат диссертации на соискание ученой степени кандидата экономических наук. Москва, 2004. 25 с.

24. Гладкий В.Д. Словарь нумизмата. Млсква: Центрполиграф, 2006. 377 с.

25. Лунц Л.А. Деньги и денежные обязательства в гражданском праве. Москва : Статут, 2004. 350 с.

26. Селищев А.С. Деньги. Кредит. Банки. Санкт-Петербург : Питер Пресс, 2007. 427 с.

27. Везерфорд Д. История денег: борьба за деньги от песчаника до киберпространства. Москва : Терра - Книжный клуб, 2001. $320 \mathrm{c.}$

28. Брагинский М.И., Витрянский В.В. Договорное право. Книга пятая. Том 2: Договоры о банковском вкладе, банковском счете; банковские расчеты. Конкурс, договоры об играх и пари. Москва : Статут, 2011. 623 с.

29. Ефимова Л.Г. Правовые проблемы безналичных денег. Хозяйство и право. 1997. № 2. С. $28-49$.

30. Шимон С.І. Безготівкові гроші як об’єкти цивільних прав (замітки до наукової дискусії). Юридична Україна. 2015. № 7-8. C. 47-52.

31. Верховна Рада України. Про Національний банк України : Закон України від 20 травня 1999 р. № 679-XIV; зі змінами. URL : https://zakon.rada.gov.ua/laws/show/679-14.

32. Шильдина М.В. Денежные суррогаты, криптовалюта и электронные денежные средства. Евразийский Союз Ученых (ECУ). 2016. № 30. C. 81-82.

33. Parker L. Bitcoin regulation overhaul in Japan. 2017. URL: https://bravenewcoin.com/news/bitcoin-regulation-overhaulin-japan.

34. Bundesministerium der Finanzen. Betreff "Umsatzsteuerliche Behandlung von Bitcoin und anderen sog. virtuellen Währungen; EuGH-Urteil vom 22. Oktober 2015, C-264/14, Hedqvist”. GZ III C 3 - S 7160-b/13/10001; DOK 2018/0163969. 27. Februar 2018. URL:http://www.bundesfinanzministerium.de/Content/DE/Downloads/BMF_Schreiben/Steuerarten/ Umsatzsteuer/Umsatzsteuer-Anwendungserlass/2018-02-27-umsatzsteuerliche-behandlung-von-bitcoin-und-anderen-sogvirtuellen-waehrungen.pdf;jsessionid=41D281B5241D47C388EF2F220B43C946? blob=publicationFile\&v=1.

35. Wenhao S. Regulation Of Cryptocurrency In China. 2020. URL : https://www.mondaq.com/china/fin-tech/944330/ regulation-of-cryptocurrency-in-china.

36. Національний банк України. Офіційне інтернет-представництво. Роз'яснення щодо правомірності використання в Україні «віртуальної валюти/криптовалюти» Bitcoin від 10 листопада 2014 p. URL : https://www.bank.gov.ua/control/ uk/publish/article?art_id=11879608.

\section{References:}

1. The European Parliament and the Council (2009) Directive of 16 September 2009 on the taking up, pursuit and prudential supervision of the business of electronic money institutions amending Directives 2005/60/EC and 2006/48/EC and repealing Directive 2000/46/EC. URL : https://eur-lex.europa.eu/legal-content/EN/TXT/?uri=celex\%3A32009L0110.

2. Kumar K. (2019) Prepaid Payment Instruments (PPIs) and its Regulations. URL : https://blog.ipleaders.in/prepaid-paymentinstruments-and-its-regulations/

3. The National Diet (2009) Payment Services Act. Law number: Act No. 59 of June 24, 2009. URL : http://www. japaneselawtranslation.go.jp/law/detail/?id=3078\&vm=02\&re $=02$.

4. Lagutin I.B. (2015) Alternativnoe denezhnoe obrashchenie i regionalnoe (mestnoe) denezhnoe obrashchenie: voprosy teorii, praktika osushchestvleniia i pravovogo regulirovaniia [Alternative money circulation and regional (local) money circulation: questions of theory, practice of implementation and legal regulation]. Provintcialnye nauchnye zapiski. № 2. P. 13-20.

5. European Central Bank (2012) Virtual currency schemes. URL : https://www.ecb.europa.eu/pub/pdf/other/ virtualcurrencyschemes201210en.pdf.

6. European Central Bank (2015) Virtual currency schemes - a further analysis. URL : https://www.ecb.europa.eu/pub/pdf/ other/virtualcurrencyschemesen.pdf.

7. European Central Bank (2016) Opinion CON/2016/49 on a proposal for a directive of the European Parliament and of the Council amending Directive (EU) 2015/849 on the prevention of the use of the financial system for the purposes of money laundering or terrorist financing and amending Directive 2009/101/EC. URL: https://eur-lex.europa.eu/legal-content/EN/ TXT/PDF/?uri=CELEX:52016AB0049\&from=EN

8. European Court of Justice (2015) Reports of Cases Skatteverket v David Hedqvis. URL : http://eur-lex.europa.eu/legalcontent/EN/TXT/PDF/?uri=CELEX:62014CJ0264. 
9. The European Parliament and the Council (2018) Directive 2018/843 amending Directive (EU) 2015/849 on the prevention of the use of the financial system for the purposes of money laundering or terrorist financing, and amending Directives 2009/138/EC and 2013/36/EU. URL : https://eur-lex.europa.eu/legal-content/EN/TXT/?uri=CELEX\%3A32018L0843.

10. Tanklevska N.S., Petrenko V.S., Karnaushenko A.S. (2017) Ekonomichna sutnist ta vydy kryptovaliuty u sviti [Economic essence and types of cryptocurrency in the world]. Naukovo-vyrobnychyizhurnal “Biznes-navihator”. № 4-2 (43). P. $133-138$.

11. Communiqué Finance Ministers \& Central Bank Governors (2018). URL: https://back-g20.argentina.gob.ar/sites/default/ files/media/communique g20.pdf.

12. Melnychuk M.O. (2017) Virtualna valiuta yak yurydychnyi fenomen v elektronnii komertsii [Virtual currency as a legal phenomenon in e-commerce]. Naukovyi visnyk Khersonskoho derzhavnoho universytetu. № 5. P. 106-109.

13. Protsenko A.T. (2016) Pravove rehuliuvannia obihu elektronnykh hroshei v Ukraini [Legal regulation of electronic money circulation in Ukraine] : dys. ... kand. yuryd. nauk. K., 202 pp.

14. Popikov A.A. (2016) Kriptovaliuta Bitcoin kak finansovyi instrument virtualnoi ekonomiki [Bitcoin cryptocurrency as a financial instrument of the virtual economy]. Voprosy innovatcionnoi ekonomiki. № 6. P. 89-106.

15. European Banking Authority (2019) Report with advice for the European Commission. URL : https://eba.europa.eu/ documents/10180/2545547/EBA+Report+on+crypto+assets.pdf.

16. European Central Bank (2020) Report on a digital euro. URL : https://www.ecb.europa.eu/pub/pdf/other/Report_on_a digital_euro 4d7268b458.en.pdf.

17. G7 Working Group on Stablecoins (2019) Investigating the impact of global stablecoins. URL : https://www.bis.org/cpmi/ publ/d187.pdf.

18. Xiao B., Wibawa T. (2019) China passes cryptography laws, laying framework for a national digital currency. URL : https:// www.abc.net.au/news/2019-10-30/china-passes-cryptography-laws-national-digital-currency/11645984.

19. Anstey C., Chen L., Xie H. (2020) China’s Digital Currency Could Challenge Bitcoin and Even the Dollar. URL : https:// www.bloomberg.com/news/articles/2020-06-01/china-is-making-cryptocurrency-to-challenge-bitcoin-and-dollar.

20. Kolodiazhnyi R. (2020) E-grivnia $\mathrm{v}$ deistvii: skoro my smozhem rasplachivatsia $\mathrm{v}$ magazinakh tcifrovoi natcvaliutoi [E-hryvnia in action: soon we will be able to pay in stores with digital national currency]. URL : https:/finance.liga.net/ bank/opinion/e-grivnya-v-deystvii-skoro-my-smojem-rasplachivatsya-v-magazinah-tsifrovoy-natsvalyutoy.

21. Natsionalnyi bank Ukrainy (2019) Natsionalnyi bank prodovzhyt vyvchaty mozhlyvist vypusku vlasnoi tsyfrovoi valiuty e-hryvni [The National Bank will continue to study the possibility of issuing its own digital currency - e-hryvnia]. URL : https://bank.gov.ua/ua/news/all/natsionalniy-bank-prodovjit-vivchati-mojlivist-vipusku-vlasnoyi-tsifrovoyi-valyuti--e-grivni.

22. Natsionalnyi bank Ukrainy (2019) Analitychna zapyska za rezultatamy pilotnoho proektu "E-hryvnia" [Analytical note on the results of the pilot project "E-hryvnia"]. URL : https://bank.gov.ua/admin_uploads/article/Analitichna_zapiska_Egrivnya.pdf? $\mathrm{v}=4$.

23. Predein E.V. (2004) "Denezhnye surrogaty" v ekonomike Rossii ["Monetary surrogates" in the Russian economy]. Avtoreferat dissertatcii na soiskanie uchenoi stepeni kandidata ekonomicheskikh nauk. M., 25 pp.

24. Gladkii V.D. (2006) Slovar numizmata [Dictionary of numismatists]. M., 377 pp.

25. Luntc L.A. (2004) Dengi i denezhnye obiazatelstva $v$ grazhdanskom prave [Money and liabilities in civil law]. M., 350 pp.

26. Selishchev A.S. (2007) Dengi. Kredit. Banki [Money. Credit. Banks]. Sankt-Peterburg, 427 pp.

27. Vezerford D. (2001) Istoriia deneg: borba za dengi ot peschanika do kiberprostranstva [The History of Money: The Struggle for Money from Sandstone to Cyberspace]. M., $320 \mathrm{pp}$.

28. Braginskii M.I., Vitrianskii V.V. (2011) Dogovornoe pravo. Kniga piataia. Tom 2: Dogovory o bankovskom vklade, bankovskom schete; bankovskie raschety. Konkurs, dogovory ob igrakh i pari [Contract law. Book five. Volume 2: Agreements on bank deposit, bank account; bank settlements. Competition, game agreements and bets]. M., 623 pp.

29. Efimova L.G. (1997) Pravovye problemy beznalichnykh deneg [Legal problems of non-cash money]. Khoziaistvo i pravo. № 2. P. $28-49$.

30. Shymon S.I. (2015) Bezghotivkovi hroshi yak obiekty tsyvilnykh prav (zamitky do naukovoi dyskusii) [Non-cash money as objects of civil rights (notes to the scientific discussion)]. Yurydychna Ukraina. № 7-8. P. 47-52.

31. Verkhovna Rada Ukrainy (1999) Pro Natsionalnyi bank Ukrainy. Zakon Ukrainy vid 20 travnia 1999 roku № 679-XIV; zi zminamy [About the National Bank of Ukraine. Law of Ukraine of May 20, 1999 № 679-XIV; with changes]. URL : https://zakon.rada.gov.ua/laws/show/679-14.

32. Shildina M.V.(2016) Denezhnye surrogaty, kriptovaliuta i elektronnye denezhnye sredstva [Cash surrogates, cryptocurrencies and electronic funds]. Evraziiskii Soiuz Uchenykh (ESU). № 30. P. 81-82.

33. Parker L. (2017) Bitcoin regulation overhaul in Japan. URL: https://bravenewcoin.com/news/bitcoin-regulation-overhaulin-japan.

34. Bundesministerium der Finanzen (2018) Betreff "Umsatzsteuerliche Behandlung von Bitcoin und anderen sog. virtuellen Währungen; EuGH-Urteil vom 22. Oktober 2015, C-264/14, Hedqvist”. GZ III C 3 - S 7160-b/13/10001; DOK 2018/0163969. 27. Februar 2018. URL:http://www.bundesfinanzministerium.de/Content/DE/Downloads/BMF_Schreiben/Steuerarten/ Umsatzsteuer/Umsatzsteuer-Anwendungserlass/2018-02-27-umsatzsteuerliche-behandlung-von-bitcoin-und-anderen-sogvirtuellen-waehrungen.pdf;jsessionid=41D281B5241D47C388EF2F220B43C946?_blob=publicationFile\&v=1.

35. Wenhao S. (2020) Regulation Of Cryptocurrency In China. URL : https://www.mondaq.com/china/fin-tech/944330/ regulation-of-cryptocurrency-in-china.

36. Natsionalnyi bank Ukrainy (2014) Ofitsiine Internet-predstavnytstvo. Roziasnennia shchodo pravomirnosti vykorystannia v Ukraini "virtualnoi valiuty/kryptovaliuty" Bitcoin vid 10.11.2014 [Clarification on the legality of using Bitcoin "virtual currency / cryptocurrency" in Ukraine dated November 10, 2014]. URL : https:/www.bank.gov.ua/control/uk/publish/ article?art_id=11879608. 